\title{
Change, Continuity and Political Crisis. Montenegro's Political Trajectory (1988-2016)
}

\section{Kenneth Morrison}

\begin{abstract}
Montenegro has passed through more than two decades of flux to reach its current status as a NATO member and European Union (EU) candidate. The smallest republic of the Socialist Federal Republic of Yugoslavia, Montenegro's modern history has been characterised by both significant change (in statehood) and relative continuity (in leadership). The author focuses on the period between the republic's first multi-party elections in 1990, through the 1997 split within the ruling Democratic Party of Socialists (DPS) and the May 2006 independence referendum to the parliamentary elections of 2016 and the country's ongoing political crisis, assessing the most significant political developments throughout the aforementioned period.
\end{abstract}

Kenneth Morrison is Professor of Modern Southeast Europan History and Co-Director of the Jean Monnet Centre for European Governance at De Monfort University in Leicester.

In May 2016, Montenegro celebrated the ten-year anniversary of the re-establishment of its independence, and it had been a decade in which its government faced myriad challenges. The referendum itself was a pivotal moment in Montenegro's modern history and its trajectory since has been shaped by it. Held on 21 May 2006, the referendum sought to determine whether the republic would remain a partner within the state union of Serbia \& Montenegro, created as a consequence of the March 2002 'Belgrade Agreement', or become an independent state. A narrow majority of $55.5 \%$ (the threshold was set at 55 per cent) of the republic's citizens opted for the latter, heralding Montenegro's re-emergence as an internationally recognised independent state. The 'Yes' and 'No' campaigns had been bitterly fought by the respective blocs advocating these options; accusations of voting irregularities, coercion of the media and voter manipulation were commonplace. ${ }^{1}$ Thus Montenegro entered into this new era with a divided body politic and embitterment among a significant minority $-44.5 \%$ of the population had voted to retain the joint state-, many of whom felt aggrieved by the result.

\footnotetext{
${ }^{1}$ OSCE Press Release, 'International Referendum Observation Mission: Referendum on State Status, Republic of Montenegro (Serbia and Montenegro), Podgorica, 22 May 2006.
} 
On 3 June 2006, independence was formally declared, and Montenegro thereafter made notable progress, becoming a member of the United Nations (UN) and other international institutions while making strides toward achieving the government's core objective, EuroAtlantic integration. Montenegro received an invitation to join NATO in December 2015despite the lack of public consensus on the issue-, formally became part of the military alliance in June 2017, and continues on a positive trajectory towards EU membership, probably the most likely member drawn from the 'Western Balkan Six'. ${ }^{2}$ But the referendum result divided the Montenegrin body politic into winners and losers, which only served to consolidate power in the hands of those elites that belonged to the former, particularly within the ruling Democratic Party of Socialists (Demokratska partija socijalista, DPS). In the wake of the referendum, the DPS further consolidated its position as the 'state party', and the opaque boundaries between the ruling party and the state remained. ${ }^{3}$ Opposition attempts to challenge this situation have, thus far, brought little success but have generated and sustained a political crisis that still persists. The country is now a NATO member and is moving, albeit incrementally, toward European Union (EU) membership - possibly by 2025. However, a lengthy internal political crisis, and a highly politicised trial of opposition MPs accused of involvement with the attempted 'state coup' of October 2016, continues and the Montenegrin political landscape remains tense and fragmented.

\section{From Multi-Party Elections to the DPS Split, 1990-97}

Montenegro's current situation cannot be understood without addressing the republic's trajectory in the decade and a half preceding the May 2006 referendum. Montenegro, as the smallest of the six republics of the Socialist Federated Republic of Yugoslavia (SFRJ), was significantly impacted by the disintegration of that state. In 1989, after a protracted economic crisis in which many Montenegrin enterprises failed, the so-called 'anti-bureaucratic revolution'-in reality an internal coup within the ruling Montenegrin League of Communists (Savez komunista Crne Gore, SKCG)—brought to power younger political elites loyal to the then Serbian president, Slobodan Milošević. ${ }^{4}$ Under the slogan Mi znamo kako! (We know how!), the

\footnotetext{
2 The Western Balkan Six are: Serbia, Montenegro, Bosnia \& Herzegovina, Macedonia (FYROM), Kosovo, and Albania.

3 The OSCE have also noted on more than one occasion the "continued blurring of division between the Montenegrin state and the governing party." See, for example, OSCE/ODIHR, Republic of Montenegro: Presidential Election, 6 April 2008, OSCE/ODIHR Election Observation Mission Final Report, Warsaw, 1 September 2008, 7.

${ }^{4}$ Elizabeth Roberts, Realm of the Black Mountain: A History of Montenegro, London: Hurst \& Co., $2007,432$. In his insightful study of the anti-bureaucratic revolutions, Nebojša Vladisavljević argues that the degree of control asserted by Milošević might be overstated. While 1989 was a coup, it was achieved largely as a consequence of
} 
'young, handsome and intelligent' troika of Momir Bulatović, Svetozar Marović and Milo Djukanović cast themselves as a new generation with novel ideas. ${ }^{5}$ In the subsequent multi-party elections (Montenegro's first), the SKCG won 83 of the 125 seats in parliament, and in June 1991, Milo Djukanović formed his first government, becoming Europe's youngest prime minister at the age of just $28 .{ }^{6}$ The party officially changed its name to the Democratic Party of Socialists-a largely cosmetic change. The structure of the party remained largely intact, with the offices, personnel, assets and funds of the old SKCG transferring smoothly to the DPS.

The trajectory of Montenegrin politics was, however, determined by events elsewhere in the SFRJ. As armed conflict intensified in Croatia throughout the spring and summer of 1991, the Montenegrin government frequently warned of the need for its border with Croatia to be defended. With the beleaguered Croats already in retreat in Eastern Slavonia, a strong second front would put them under further pressure; a thrust from Montenegrin units on Croatia's southern border could quicken Croatia's capitulation. The pages of Montenegro's only daily newspaper Pobjeda were replete with anti-Croat propaganda, and even stark warnings of thousands of Ustaše (Croatian fascists) amassing at the Croatian-Montenegrin border. ${ }^{7}$ The paper's editorials, as part of the Rat za mir (War for Peace) propaganda campaign, featured numerous DPS figures making their case for war. Framed as a defensive war, Montenegrins were encouraged to think of themselves not as aggressors but as defenders of Yugoslavia, fighters against resurgent fascism, even liberators of Dubrovnik. But the subsequent 'War for Peace' was a disaster not only for Serbia, but also for Montenegro. Television images of the 'Pearl of the Adriatic' being shelled by the Yugoslav National Army formed mostly by Serb and Montenegrin soldiers were transmitted across the world, creating controversy and revulsion.

The Montenegrin leadership, shaken by the course of events, sought to distance itself from the Dubrovnik campaign; and it was within this context that Bulatović took a significant political gamble. During the 'Hague Conference', organized by the European Community (EC) and chaired by Lord Peter Carrington, he boldly took a decision that would strain the consensus between Titograd (Podgorica) and Belgrade. The 'Carrington Plan' envisaged the SFRJ becoming a loose association of independent states that would have the status of subjects under

\footnotetext{
genuine mass protest and as the fact that the leadership was discredited. See Nebojša Vladisavljević, Serbia's Antibureacratic Revolution: Milošević, the Fall of Communism and Nationalist Mobilization, Basingstoke: Palgrave MacMillan, 2008.

${ }^{5}$ Veseljko Koprivica / Branko Vojičić, Prevrat '89, Podgorica: Liberalni Savez Crne Gore, 1994, 341. See also Srdjan Darmanović, "The Peculiarities of Transition in Serbia and Montenegro," in Dragica Vujadinović et al, eds, Between Authoritarianism and Democracy: Serbia, Montenegro, Croatia, Belgrade: CEDET, $2003,156$.

${ }^{6}$ For a political biography of Milo Djukanović see Kenneth Morrison, 'The Political Life of Milo Djukanović',

7 Živko Andrijašević, Nacrt za ideologiju jedne vlasti, Bar: Conteco, 1999, 95.
} 
international law. ${ }^{8}$ Electing to accept the plan, Bulatović announced that Montenegro would sign. ${ }^{9}$ For many in Montenegro, Bulatović's actions were nothing short of treachery, and upon his return, he attempted to persuade delegates in the Montenegrin assembly. ${ }^{10}$ Opinion, however, turned sharply against him, and pressure was also applied by Belgrade. A variant of the SFRJ (a 'rump' Yugoslavia) could continue to exist if two or more republics wished to remain in federation. On 30 October 1991, Serbia and Montenegro proposed an amendment to the Carrington Plan, which allowed those states that did not wish to secede from Yugoslavia to establish a successor federal state. Thus, plans were made by elites in Serbia and Montenegro to establish the 'Federal Republic of Yugoslavia' (Savezna republika Jugoslavija, SRJ), comprising approximately $44 \%$ of the population and around $40 \%$ of the territory of the SFRJ. ${ }^{11}$ Despite opposition protests, these plans were made public only two months before its realization; constitutional experts took only five days to write the new constitution, and opposition parties were not consulted. ${ }^{12}$

To realize the creation of the SRJ, the Montenegrins would need to approve its creation by referendum. The Montenegrin government adopted the 'Law on Referendum' only a week before the vote, limiting the scope for public debate. On 1 March 1992, in a seemingly comprehensive outcome, an overwhelming number of Montenegrins voted to preserve union with Serbia. $95.7 \%$ of those who voted chose to remain in federation with Serbia. The legitimacy of the referendum was brought into question, however, by the relatively low turnout of $66 \%$. Collectively, the opposition denounced the 'Žabljak Constitution'-named after the Montenegrin town where the nomenklatura had met in order to create the state - arguing that it was an unequal construction, and that the SRJ was dysfunctional in that it comprised two federal units of disproportionate scale, population and economic interests, placing Montenegro at a disadvantage. ${ }^{13}$

In subsequent years, the DPS remained dominant, though the relationship between the ruling elites in Serbia and (some) within the DPS would become increasingly strained. The two

\footnotetext{
${ }^{8}$ Interview with Lord Carrington, 4 January 1995, Death of Yugoslavia Archive, Roll 73E, U-BIT, No. 121.

9 Slobodan Vučetić, "Serbia and Montenegro: From Federation to Confederation," in Dragica Vujadinović et al, eds, Between Authoritarianism and Democracy, 73.

${ }^{10}$ For Bulatović's own view of these events see Momir Bulatović, Pravila ćutanja, Belgrade: Alfa, 2003.

${ }^{11}$ Slobodan Vučetić, "Serbia and Montenegro: From Federation to Confederation," in Dragica Vujadinović et al, eds, Between Authoritarianism and Democracy, 73.

12 Robert Thomas, Serbia under Milošević: Politics in the 1990s, London: Hurst \& Co., 1999, 120. For the opposition protests in advance of the referendum see Srdja Pavlović / Milica Dragojević, 'Peaceniks and Warmongers: Anti-War Activism in Montenegro, 1989-1995', in Bojan Bilić / Vesna Janković, eds, Resisting the Evil: Post-Yugoslav Anti-War Contention, Baden-Baden: Nomos, 2012, 137-58.

${ }^{13}$ See D Vuković, 'Onamo ili ovdje?', Monitor, Podgorica, 17 July 1992, 13.
} 
federal units had remained united through years of United Nations (UN) sanctions and the 199295 war in Bosnia and Herzegovina, but with the signing of the Dayton Agreement in November 1995, cracks started to appear in the relationship. The fuse was eventually lit by Djukanović's implicit support for the Zajedno (Together) coalition-led anti-Milošević protests taking place throughout Serbia in the wake of the alleged electoral fraud. Djukanović was, however, more explicit, declaring his opposition to Milošević, and leaving little space for ambiguity or misinterpretation. Utilising the Belgrade weekly magazine Vreme as a forum, Djukanović asserted that Milošević was an 'obsolete politician' who lacked 'the ability to form a strategic vision'. 14

A split within the ranks of the DPS emerged, with Momir Bulatović, Milo Djukanović and the vice-president of the DPS, Svetozar Marović, becoming increasingly divided over the consequences of Djukanović's actions. Bulatović calculated that Milošević would overcome the crisis, while Djukanović and Marović gambled on the contrary. The split within the upper echelons of the DPS became so strained that on 24 March 1997, during a meeting of the main board, a vote was called that would ultimately determine the future direction of the party. ${ }^{15}$ Ostensibly arranged to discuss matters pertaining to wider political, economic and social issues in Montenegro and the SRJ, the meeting instead became a debate on the implications of Djukanović's actions. ${ }^{16}$ Following lengthy discussion and argument, the main board voted, and Bulatović's pro-Milošević stance was seemingly endorsed. However, amongst the seven who voted for Djukanović (and amongst those who had abstained) were some of the most powerful individuals in Montenegrin politics. ${ }^{17}$ They would be factors in convincing wavering DPS members that the party's interests were best served by supporting Djukanović. An intense internal party power struggle ensued. ${ }^{18}$ Djukanović applied significant pressure on those deemed pliable, breaking down most of those who had initially voted against him, and succeeding in building a powerful grouping within the DPS. Djukanović had, therefore, wrested control of the party in the advance of the second crucial meeting of the DPS main board on 11 July $1997 .{ }^{19}$ During that meeting, the party confirmed Djukanović's ascendancy. ${ }^{20}$

\footnotetext{
${ }^{14}$ Velizar Brajović, 'Interviju: Milo Djukanović', Vreme, Belgrade, 19 February 1997, 6-9.

15 The main board of the DPS consisted of 99 members. See Ljubisa Mitrović / Aleksander Eraković, eds., Sto dana koji su promijenili Crnu Goru, Podgorica 1997, 21-22.

${ }^{16}$ Ljubisa Mitrović / Aleaksander Eraković, eds., Sto dana koji su promijenili Crnu Goru, 1997, 21.

17 V/J. 'Do posljednjeg dana', Monitor, Podgorica, 4 April 1997, 9. See also C.K., 'Duboka privrženost zajedhičkoj domovini’ Pobjeda (Podgorica), 24 April 1997, 2.

18 V.J., Ima li pilota u DPS-u', Monitor, Podgorica, 20 June 1997, 10.

${ }^{19}$ Drasko Djuranović, 'DPS iz dva dijela', Monitor, Podgorica, 30 May 1997, 9-10.

${ }^{20}$ For a more detailed account of the 11 July DPS meeting see, Mitrović / Eraković, Sto dana koji su promijenili Crnu Goru, 337-344.
} 
Following Djukanović's successful bid for control of the DPS, both he and Bulatović sought to win the presidency. In the first round Bulatovic won by a narrow margin of only 2,200 votes with a $67 \%$ turnout, and thus a second round was required. In the second round, Djukanović gained 5,884 votes more than Bulatović (who immediately cried foul). ${ }^{21}$ Despite violent protests in Podgorica following the announcement of the result, the Djukanović faction of the DPS thereafter consolidated its position of strength, wresting control of both the party and DPS 'brand'. The pro-Milošević faction, led by Momir Bulatović, left the DPS and established the Socialist People's Party (Socijalistička narodna partija, SNP). ${ }^{22}$

\section{The Winding Road to Independence}

A cautious platform was adopted by the post-split DPS and, at this stage, there was no explicitly pro-independence position advocated by the party. Instead, they affirmed their commitment to Montenegro's role within the SRJ. But relations between Djukanović and Milošević continued to worsen following the May 1998 elections-largely fuelled by the election of Momir Bulatović as President of the SRJ, a development strongly opposed by the DPS, and a clear divide over how to deal with the growing crisis in Kosovo. In terms of the latter, the Montenegrin government sought to distance itself, declaring neutrality and advocating dialogue with Kosovo Albanians in conjunction with the EU. But continued military actions by Serb forces and retaliations by the Kosovo Liberation Army (Ushtria Çlirimtare e Kosovës, UÇK/KLA) drove Serbia, and thus the SRJ, into inexorable conflict with NATO. The Montenegrin authorities were acutely aware that despite their self-proclaimed neutrality, Montenegro was home to strategic military sites that would be targeted as part of any NATO bombing campaign. While the subsequent NATO bombing of the SRJ had significantly less impact in Montenegro than in Serbia, the internal situation in Montenegro steadily worsened as a result. A continuing flow of refugees, numbering 80,000, put a considerable strain on the government, and as NATO bombs fell on Montenegro, Djukanović's government was placed under significant pressure by both Milošević and his supporters in Montenegro. ${ }^{23}$ Milošević's capitulation after 78 days of bombing dictated that Montenegro survived the war, despite the many risks and potential for open conflict between opposing

\footnotetext{
${ }^{21}$ OSCE/ODHIR: "Republic of Montenegro: Presidential Election 5th and 18th October 1997, Final Report," $1997,5$.

${ }^{22}$ International Crisis Group, Montenegro's Socialist People's Party: A Loyal Opposition?, Europe Report 92, 28 April 2000, 3.

${ }^{23}$ Interview with Milo Djukanović in The Fall of Milošević Archive, Roll No.1/12b, 22.
} 
groups in Montenegro. ${ }^{24}$

In the wake of the NATO campaign, Djukanović continued to make the case for greater independence for Montenegro. As a means of achieving this, the Montenegrin government created its own foreign service, adopted the Deutschmark (and later the Euro) and abolished the existing visa and customs regimes. But this objective was undermined by the fall of Slobodan Milošević following the 5 October 2000 demonstrations in Belgrade. The international community now encouraged the Montenegrin government to find a solution to their problems with Serbia, but the DPS leadership continued to pursue independence. Thereafter, Montenegrin politics was defined not simply by a pro/anti-Milošević dynamic, but by the issue of statehood. Though signing the Belgrade Agreement of March 2002, which initiated the creation of the 'joint state' of Serbia and Montenegro, the issue of Montenegro's status was not brought to a conclusion. Indeed, Djukanović extracted a crucial concessionthat Montenegro could hold a referendum on independence three years from the ratification of the Belgrade Agreement. ${ }^{25}$

The assassination of the Serbian prime minister Zoran Djindjić in Belgrade on 12 March 2003 sent the 'joint state' into something of a crisis. Just one year after the signing of the Belgrade Agreement, the union seemed to be drifting. The assassination and subsequent 'Operation Sabre' in Serbia only served to strengthen the Montenegrin government's claim that Serbia was far from ready to make the kind of democratic reforms that Djindjić himself had advocated. Lack of cooperation with the International Criminal Tribunal for the former Yugoslavia (ICTY) and the EU's threat to suspend accession negotiations with the state union in 2005 was oft-used by pro-independence campaigners as a justification for why Montenegro needed to become independent. In late February 2003, just two weeks before Djindjić's assassination, the ICTY's chief prosecutor, Carla Del Ponte, had visited Podgorica whereupon she had met with Milo Djukanović, who had proceeded to complain to her that then Serbian president Vojislav Koštunica and the army were 'thwarting reforms and blocking Serbia and Montenegro's cooperation with The Hague'. According to Del Ponte, Djukanović lamented that 'Montenegro will suffer the consequences of Serbia's failure to cooperate with the tribunal'. 'Montenegro' he said, 'does not want to be a hostage to Serbia any longer'. Del Ponte added that Djukanović was also reluctant to be a witness at the Milošević trial and that doing

\footnotetext{
${ }^{24}$ Srdjan Darmanović, Montenegro Survives the War, The East European Constitutional Review 8, No.3, 1999, 12.

${ }^{25}$ See N.R. 'Solana redigovao dvije platforme', Vijesti, Podgorica, 16 March 2002, 4.
} 
so would 'damage him politically in Montenegro'. ${ }^{26}$ Thus the period during which the state union was 'functioning' was one of intense activity in Montenegro, which, despite entering into the state union agreement seemed to be charting its own course. Advocates of independence, having recovered from Djukanović's 'betrayal' in signing the Belgrade Agreement, and three subsequent presidential elections, were gaining increasing traction as it became evident that Montenegro being part of the joint state was not per se a major obstacle to the eventual scheduling of an independence referendum.

By 2004 it was evident that the Montenegrin government would schedule a referendum. In November of that year they signalled that one would indeed be scheduled by early 2006 . In late February 2005 they sent a proposal to the Serbian government that envisaged a transformation of the existing joint state into a union of independent states, but the proposal was bluntly dismissed by Vojislav Koštunica. ${ }^{27}$ As a referendum on independence became increasingly likely, Serbs in Montenegro, working in concert with Montenegrins living in Serbia, established a movement which brought unionist forces together. The result of these endeavours was the 'Movement for the Joint European State of Serbia and Montenegro' (Pokret za zajedničku evropsku državu Srbiju i Crnu Goru). Besides Montenegrin Serbs and Montenegrins living in Serbia, the majority of whom supported preservation of the union, the movement joined unionist political parties and their members in Montenegro, and a number of Serb/Montenegrin diaspora groups. Momir Bulatović's SNP did not join, however. The movement's objective was to make the strongest possible case for the preservation of the state union, to ensure that Montenegrins living in Serbia could vote in any future independence referendum, and to emphasise the brotherhood and 'unbreakable historical bonds' between Serbs and Montenegrins. ${ }^{28}$ One of the movement's core arguments was that the Montenegrin state had been 'captured' by a group of political elite members, led by Djukanović, whose objective was to separate Montenegro from Serbia in order to consolidate their own political and economic power, which, it was argued, they had been amassing since the 1997 split of the DPS. They also argued that the Montenegrin government were attempting to deny voting rights to Montenegrins residing in Serbia and, more broadly, engaged in 'whitewashing' symbols of Serbian identity from Montenegro. However, according to an International Crisis Group (ICG) report from 2005, preservation of the state union was not the sole motivating factor for members of the movement.

\footnotetext{
${ }^{26}$ Carla Del Ponte (with Chuck Sudetic), Madame Prosecutor: Confrontations with Humanity's Worst Criminals and the Culture of Impunity, New York 2009, 171.

${ }^{27}$ International Crisis Group, 'Montenegro's Independence Drive', Crisis Group Report No.169, Brussels, 7 December 2005, 8 .

${ }^{28}$ See Draško Djuranović, ‘Terazije za krivo mjerenje', Monitor, Podgorica, 18 February 2005, 10-11.
} 
Djukanović's eight years in power had left many of them out in the cold, and a number were 'anxious to have a chance to come to power and share in the distribution of wealth that is taking place under the current privatization drive'. ${ }^{29}$

Conversely, the 'Movement for a Sovereign and Independent Montenegro' (Pokret za samostalnu i nezavisnu Crnu Goru) was formed in 2005, their objective being to gather proindependence forces, to make a robust case for independence and to generate support for the independence project. In so doing they were largely, if not entirely, successful. The logic for them was simple, if risky. Gain independence first, utilising the rather undemocratic DPSDjukanović power structure, and then consolidate democracy in the future.

At this stage, however, the independence project could have easily been derailed. It remained unclear exactly who would be eligible to vote in a referendum and whether Serb political parties in Montenegro would participate. It was later agreed that they would, if the EU oversaw the referendum process. The EU's position, however, was to encourage both Serbia and Montenegro to implement the Belgrade Agreement and to strengthen the state union's institutions. To advocates of Montenegro's independence this was seen as a paradoxical position for the EU to take, defending the continuation of the successor to Milošević's construction (the SRJ). They perceived the state union as an imposition by the EU in cahoots with official Belgrade. This perception was further consolidated when, in June 2005, Vojislav Koštunica was received by EU Commissioner Olli Rehn in Brussels. In an effort to derail a referendum, Koštunica handed Rehn a list of 264,000 names: Montenegrins living in Serbia, who, Koštunica argued, should be permitted to vote. The EU, however, gave no official response to 'Koštunica's list' ${ }^{30}$

Subsequently, the right to vote in the Montenegrin referendum was given to those who 'normally enjoy suffrage for presidential and parliamentary elections in Montenegro: an eligible voter was one aged over 18 years, who held Montenegrin citizenship and who had been permanently resident in Montenegro for a period of at least 24 months. By law, these qualifications meant that an eligible voter also included any Serbian citizen with a permanent residence in Montenegro for the same period, as well as a Montenegrin citizen who was temporarily resident in Serbia or abroad but who had retained a registered permanent residence

\footnotetext{
${ }^{29}$ International Crisis Group (ICG), 'Montenegro’s Independence Drive', 11.

30 OSCE/ODHIR, 'Republic of Montenegro: Referendum on State-Status 21 May 2006 - OSCE/ODHIR Referendum Observation Mission Final Report, Warsaw, 4 August 2006, 8. For the role of diaspora in the Montenegrin referendum see Kenneth Morrison, Nationalism, Identity and Statehood in Post-Yugoslav Montenegro, London: Bloomsbury, 2018, 127-128.
} 
at an address in Montenegro' ${ }^{31}$

This, of course, excluded those Montenegrins who were registered as permanently resident in Serbia. Montenegrins living in the United States, Australia and Germany, to name but a few, could, however, vote in the referendum. On 10 November 2005, the European Commission (EC) sent a 'non-paper' to the Montenegrin government cautioning that failure to reach a consensus on the referendum with the opposition could have 'severely negative consequences for Montenegro's future aspirations for European integration', and that if Montenegro chose to leave the state union it would 'not inherit the right to an international legal personality' (the latter was, however, already enshrined in the Belgrade Agreement). ${ }^{32}$ In the knowledge that the existing political polarisation and the divided nature of Montenegrin society generally held the potential for violent conflict, the EU attempted to counter such dark scenarios by discouraging the Montenegrin government from seeking independence. But when it became evident that the latter would do so in any event, the EU reluctantly shifted into the role of arbiter in advance of (and throughout) the referendum process. ${ }^{33}$ They subsequently endeavoured to reach agreement with Montenegrin political parties over a set of rules and conditions that would be acceptable to all, and it proved to be pivotal. Indeed, the role of the EU would be crucial in reaching a consensus on the rules of the referendum itself, something which the Montenegrin government and opposition had been unable to achieve independently.

The task of ensuring a smooth referendum process was awarded to a young Slovakian diplomat, Miroslav Lajčak, who in late 2005 was appointed as Javier Solana's 'Special Envoy' to Montenegro. ${ }^{34}$ A fellow Slovak, František Lipka, was chosen to chair the Republican Referendum Committee (RRC), the body that would arbitrate in disputes throughout the referendum process. But while both men were well versed in the idiosyncrasies of Balkan politics, spoke Serbian/Montenegrin proficiently and were diplomats who came from a Slavic country (Czechoslovakia) that had had, in January 1993, its own 'velvet divorce'—which had

\footnotetext{
31 OSCE/ODHIR, 'Republic of Montenegro: Referendum on State-Status 21 May 2006 - OSCE/ODHIR Referendum Observation Mission Final Report, Warsaw, 4 August 2006, 8. For the role of diaspora in the Montenegrin referendum see Kenneth Morrison, Nationalism, Identity and Statehood in Post-Yugoslav Montenegro, 127-128.

32 EC Troika 'non-paper' of 10 November 2005, quoted in International Crisis Group, 'Montenegro's Independence Drive', 10.

${ }^{33}$ The United States adopted a more hands-off approach to the issue of Montenegro's independence. According to the International Crisis Group, the US Ambassador made it clear that his country would not take a position on Montenegro's independence and that the US considered it to be an internal (state union) issue. See, Montenegro's Independence Drive,' 12.

${ }^{34}$ Miroslav Lajčak would, in 2007, take over from Christian Schwarz-Schilling as the international community's High Representative (HR) for Bosnia in Herzegovina in early 2007.
} 
led to the Czech Republic and Slovakia becoming independent states-reaching agreement proved problematic, impeded from the outset by fundamental disagreements about what level of majority would be legitimising the outcome of the referendum. Both men would, however, subsequently play a pivotal role in reaching a basic consensus between Montenegro's polarised political elites before the referendum and continue to do so throughout the referendum process.

The EU's first intervention was to challenge Montenegro's 'Law on Referendum' dating from February 2001, which stipulated that the referendum result would be valid if one bloc received (one vote) more than fifty percent of the registered electorate. ${ }^{35}$ To clarify the imposition of standards with regard to the referendum the Parliamentary Assembly of the Council of Europe (PACE) tasked the so-called Venice Commission (VC) with providing expert-informed recommendations on the referendum process, which by December 2005 they had completed. The VC is the commonly-used name for the European Commission for Democracy Through Law (ECDTL), i. e. the constitutional arm of the Council of Europe. Thereafter, it was agreed in February 2006 that for the referendum result to be deemed legitimate, $55 \%$ of the valid votes must be cast in favour of either a 'yes' or 'no' option, and that at least $50 \%$ (plus one) of the Montenegrin electoral body (i. e. all registered voters) must cast their votes. On the basis of this rather novel imposition, the Montenegrin government adopted a new 'Law on the Referendum on State Legal Status' on 1 March $2006 .{ }^{36}$ Furthermore, the Law on the Referendum also finalised the referendum question itself: 'Do you want the Republic of Montenegro to be an independent state with full international and legal personality?'

With these parameters established, pre-referendum campaigns now de facto commenced. In preparation for the referendum, the OSCE Office for Democratic Institutions and Human Rights (OSCE/ODHIR) established a Referendum Observation Mission (ROM) to observe the campaign and the voting process. Two administrative bodies worked alongside the Republican Referendum Committee (RRC), and these were composed of twenty-one municipal referendum commissions (MRCs) and 1,118 polling boards (PBs). Membership of each body was distributed equally between pro-independence and unionist political actors. Two commissions were also established (again, with a balanced membership) to monitor the media and campaign financing.

\section{The Independence Referendum Campaign}

\footnotetext{
${ }^{35}$ See OSCE, 'Assessment of the Referendum Law: Republic of Montenegro, Federal Republic of Yugoslavia', Warsaw, 6 July 2001.

${ }^{36}$ OSCE/ODIHR, 'Referendum Observation Mission 2006, Republic of Montenegro (Serbia and Montenegro), Interim Report 1', Podgorica, 28 March - 20 April 2006.
} 
The pro-independence and unionist blocs began their respective referendum campaigns in early May 2006. The referendum environment was marked by a generally peaceful political process. Both sides respected competing arguments and the right to convey them, and aside from a few minor incidents, the respective pro-independence and unionist campaigns were conducted in a generally positive spirit. ${ }^{37}$ Not unfamiliar with this territory-the DPS had mastered the art of campaigning during the late $1990 \mathrm{~s}$ - the pro-independence campaign proved to be rather impressive, excellently planned and delivered, even aesthetically seductive. The first of the proindependence rallies was, appropriately, held in the historical capital of Cetinje. The proindependence campaign was also notable for its inclusion of ethnic minorities. The DPS-led government had forged stronger links with Muslim/Bosniak and Albanian parties, since the latter had in 1997 joined Djukanović's anti-Milošević coalition. Unlike the unionist bloc, who aimed their campaign almost exclusively at ethnic Serbs and Montenegrins, the DPS' emphasis was placed quite significantly on the participation of Montenegro's ethnic minorities, as they were almost certain that they would garner significant support from them. Demonstrative of the strategy of incorporating minorities and minority concerns was the nature of the campaign literature and television advertising. The pro-independence campaign literature specifically both used Albanian and Serbian (Latin and Cyrillic) language and conveyed the message that an independent Montenegro would be a democratic, multiethnic state. In predominantly Orthodox areas 'Da' (Montenegrin/Serbian for 'Yes') posters were omnipotent, while in predominantly Albanian areas posters adorned with 'Po' (Albanian for 'Yes') were ever-present. It proved something of a master stroke.

The unionist bloc brought together all of those parties who supported union. Beyond the SNP, these were the Serbian People's Party (Srpska narodna stranka, SNS), the People's Party (Narodna Stranka, NS), and the Democratic Serb Party (Demokratska srpska stranka, DSS). They engaged the Belgrade-based PR agency Incognito to direct their campaign. The commonality was their Serb identity, but much of the unionist campaign focused upon what they argued was the corrupt character of Montenegro's government, placing particular emphasis on Milo Djukanovic's links with organised crime and playing on fears that he and his DPS associates would, in the event of independence, transform Montenegro into a 'private state' within which his opponents would be economically and politically marginalised. ${ }^{38}$ The cornerstone of the unionist arguments were that Serbia and Montenegro in union were a

\footnotetext{
${ }^{37}$ See OSCE/ODHIR, 'Republic of Montenegro: Referendum on State-Status 21 May 2006 - OSCE/ODHIR Referendum Observation Mission Final Report, Warsaw, 4 August 2006, 9.

${ }^{38}$ See G.N. 'Djukanović: U nezavisnoj Crnoj Gori niko neće biti poražen', Pobjeda, Podgorica, 17 May 2006, 3.
} 
stronger economy than the sum of their parts, that there were strong cultural bonds between the republics of Serbia and Montenegro, and that Serbs and Montenegrins possessed strong, indeed unbreakable, ethnic and historical bonds. Economic issues really were at the heart of their campaign, issues of tax, corporate registration, property ownership rights, citizenship, pensions, and health-care provision being predominant.

While the unionist bloc rightly acknowledged the importance of the youth vote, they nevertheless directed their campaign primarily at the Serb and Montenegrin communities. Typically, they drew most of their support from the northern Montenegrin municipalities and thus their campaign was primarily aimed at the Orthodox populations of those areas. This on the whole rather narrow focus defined their campaign, and while they could guarantee they would receive the votes of Montenegro's Serbs, their message held little attraction for Muslim/Bosniak or Albanian voters. In any event, unionist promotional material was written only in Cyrillic script. But the unionists did endeavour to run a positive and moderate campaign. Indeed, unlike previous election campaigns, symbols of Serbian nationalism were largely absent. Instead, unionist politicians focused on what they argued were the benefits for retaining the union with Serbia. Economic, cultural, and historical reasons were most frequently cited, and while the majority of the unionist campaigning focused substantially on these justifications, personal attacks against Milo Djukanović were commonplace throughout.

On the eve of the referendum the leaders of both blocs underlined the importance of the referendum being conducted in a peaceful manner, and that the outcome, whatever it may be, should be respected. ${ }^{39}$ On referendum day itself turnout was high (estimated to be 86 per cent), and there were long queues at a number of polling stations, with some citizens waiting for hours to cast their votes. The referendum was monitored by the OSCE/ODHIR's Referendum Observation Mission (ROM) alongside observers from the OSCE Parliamentary Assembly (OSCE PA), the Parliamentary Assembly of the Council of Europe (PACE), the Congress of Local and Regional Authorities of the Council of Europe (CLRAE), and representatives from the European Parliament (EP). These bodies collectively formed the International Referendum Observation Mission (IROM).$^{40} \mathrm{~A}$ few very minor irregularities occured, as OSCE observers reported suspicious activities which may have indicated vote-buying schemes on the part of the pro-independence bloc, as well as some issues with unsealed ballot boxes, and a number of instances where voters were observed taking photographs of their marked ballot papers. Beyond

\footnotetext{
${ }^{39}$ V. Žugić, 'Neka 22. maj bude evropski i miran', Vijesti, Podgorica, 18 May 2006, 2.

40 OSCE/ODHIR, 'International Referendum Observation Mission: Referendum on State Status, Republic of Montenegro (Serbia and Montenegro), Podgorica, 22 May 2006.
} 
this, the day passed without more significant difficulties. ${ }^{41}$ There was, of course, the thorny issue of the possibility that the referendum result could fall between 50 and $55 \%$ - the so-called siva zona (grey zone). Such a result would mean that there was no clear resolution to the "statehood question' and that both pro-independence and unionist supporters would take to the streets claiming victory, raising the possibility of violence and instability.

When polling stations closed at 9 p.m., the air was thick with tension and anticipation. Preliminary results and a forecast of the final result were announced just thirty minutes after the polls had closed by the NGO Centre for Monitoring and Research (Centar za monitoring $i$ istraživanje, CEMI). CEMI carefully selected initial reports from polling stations throughout Montenegro to represent the overall electorate as closely as possible. The NGO Centre for Democratic Transition (Centar za demokratsku tranziciju, CDT), perhaps having seen the chaos caused by the preliminary results given by CEMI, chose a more cautious approach. Their spokesperson, Milica Kovačević, stated that, 'We are of the opinion that the referendum commission should be allowed to complete its work and count all ballot papers. The projections show a very tight result. The CDT does not want to contribute to confusion'. ${ }^{42}$ Though only preliminary results, CEMI's announcement brought pro-independence supporters on to the streets, where they let off fireworks and, on occasion, fired pistols into the air. The leader of the unionist bloc, Predrag Bulatović (SNP) appeared on television appealing for calm and imploring unionists and their supporters not to be intimidated by the hasty celebrations of the proindependence bloc. 'All citizens of Montenegro', he said, 'must maintain peace and demonstrate tolerance and patience', adding that 'the result of the referendum is not final until the political parties on both sides accept it'. ${ }^{43}$ Nevertheless, the celebrations continued unabated and by $11 \mathrm{p}$. m. it became evident that the pro-independence bloc had indeed triumphed, albeit by a tiny margin. At 4 a.m. on 22 May 2006 Milo Djukanović gave a victory speech to DPS members in the government building before stepping outside to address the crowds who had assembled outside. There he officially declared victory and, somewhat controversially, congratulated Serbia on their own independence. ${ }^{44}$ The following morning, František Lipka, the chair of the RRC, announced the first official (but still preliminary) results: the total turnout was estimated at 86.3 $\% ; 55.5 \%$ had voted in favour of independence and $44.5 \%$ in favour of the preservation of the

\footnotetext{
${ }^{41}$ International Referendum Observation, 8.

${ }^{42}$ Statement by CDT, broadcast on Radio Televizija Crne Gore (RTCG) 21 May 2006.

${ }^{43}$ Statement by Predrag Bulatović on RTCG 1, broadcast on Radio Televizija Crne Gore (RTCG), 21 May 2006.

${ }^{44}$ Speech by Milo Djukanović on RTCG1, broadcast on Radio Televizija Crne Gore (RTCG), 22 May 2006. See also N.R. 'Djukanović: Srbijo, srećna i tebi nezavisnost', Vijesti, Podgorica, 22 May 2006, 3.
} 
state union. The 'grey zone' had been avoided by only $0.5 \% .{ }^{45}$ On 27 May the RRC confirmed the official result, based on a total turnout of $86.49 \%{ }^{46}$ The unionist bloc continued, however, to argue that there were irregularities with voting procedures on the day, but the RRC again reiterated the results for a final time on 31 May 2006, while the OSCE, upon the publication of their subsequent final referendum observation report confirmed that the referendum was 'conducted in line with OSCE and other international standards related to democratic electoral processes'. ${ }^{47}$

\section{Post-Referendum Montenegro}

Following the May 2006 referendum and the subsequent declaration of independence, the governing DPS, their coalition partners, the SDP and others comprising the 'Movement for a Sovereign and Independent Montenegro', basked in their glory. The government benefited from a lengthy post-referendum honeymoon, boosted by high levels of foreign direct investment (FDI), accompanied by a rapid (and often brash) process of privatisation that created an expanding stratum of nouveau riches. ${ }^{48}$ The opposition seemed demoralised and directionless as it stumbled into the new reality, as the DPS and their allies enjoyed the spoils of victory. Essentially a 'party of power' (and in power since 1990), it continued to grow stronger in the immediate post-referendum period. The DPS, it should be acknowledged, is more than merely a political party; it is a mechanism through which members advance their political and economic interests. Those outside the DPS or those that do not have veze (connections) with it, are at a disadvantage. Moreover, the power of the DPS's figurehead, Milo Djukanović, appeared unassailable. His instinct for political survival, and his ability to outmanoeuvre his political opponents, remained as sharp as ever-though he temporarily 'retired' from politics in 2006, passing the reins to the DPS stalwart, Željko Šturanović. However, following a difficult period for Šturanović in the wake of the outbreak of global economic crisis, Djukanović returned to take on the role of prime minster again in February $2008 .{ }^{49}$

\footnotetext{
${ }^{45}$ Statement by František Lipka (Chairman of the RRC), broadcast on Radio Televizija Crne Gore (RTCG), 22 May 2006.

${ }^{46}$ International Crisis Group, 'Montenegro’s Referendum', 12.

47 OSCE/ODHIR, 'Republic of Montenegro: Referendum on State-Status 21 May 2006 - OSCE/ODHIR Referendum Observation Mission Final Report, Warsaw, 4 August 2006, 1.

48 See Kenneth Morrison, 'Change, Continuity and Consolidation: Assessing Five Years of Montenegro's Independence', LSEE/LSE Papers on Southeast Europe, February 2011, 23.

49 Zoran Radulović, 'Na prijestolu višestruki povratnik', Monitor, Podgorica, 29 February 2008, 8-10.
} 
Throughout this period Montenegro made significant progress in their government's stated goal of joining the European Union. In June 2006, the EU established relations with Montenegro, and all member states recognised the country's independence. Just over a year later, in October 2007, Montenegro signed a Stability and Association Agreement (SAA). A formal application was submitted in December 2008, and the country's endeavours were rewarded in December 2009 when Montenegrin citizens were granted visa-free travel within the Schengen zone; an important development because it provided tangible evidence that the government's endeavours were bearing fruit. In November 2010, the European Commission published its avis (opinion) on the country's bid to become a candidate for membership, and in December 2010, Montenegro was formally awarded candidate status. In December 2011, the European Commission began the accession process, and membership negotiations began on 29 June 2012. By 2014 two chapters had been provisionally closed: those focusing on 'education and culture' (Chapter 26) and 'science and research' (Chapter 25).

Domestically, there were also significant developments. On 21 December 2010, Djukanović announced that he would once more step down as prime minster, with the mandate passing to the finance minister (and deputy prime minister), Igor Lukšić. Djukanović, however, remained the chairman of the DPS, ensuring that he kept control of the internal party discipline. But following the parliamentary elections of 2012, during which he played a significant role in the campaigning, giving speeches in all municipalities of Montenegro in the run-up to electionday, Djukanović once more announced his return as prime minister. He thus led a DPS coalition government that also included the Bosniak Party (Bošnjačka stranka, BS) and the Croatian Civic Initiative (Hrvatska građanska inicijativa, HGI).

It may have been the narrow margin of victory that led Djukanović to assess that he was indeed much better placed to assert influence over the government as prime minister, rather than as simply chairman of the dominant party within it. Moreover, the continued dominance of the DPS was, to some extent, being challenged by the formation of the Democratic Front (Demokratski front, DF), a centre-right coalition, comprising the New Serb Democracy party (Nova srpska demokratija, NOVA), the Movement for Change party (Pokret za promjene, $\mathrm{PzP}$ ), and several senior renegade SNP officials, that had increased in popularity, primarily due to the surprising degree of public support for their presidential candidate, Miodrag Lekić, who previously had served as foreign minister and as the Yugoslav Ambassador in Rome. ${ }^{50}$ Lekić

\footnotetext{
${ }^{50}$ M.J. 'Profil: Miodrag Lekić' Vijesti, Podgorica, 26 May 2013, 2. Lekić is often disparagingly referred to by Djukanović and by the pro-government media as 'Milošević's Ambassador in Rome'.
} 
has been relatively successful in casting himself as a defender of citizens' rights, attacking the government on every issue from VAT increases to their record in combating corruption and organised crime. In the April 2013 presidential elections, Lekić won an impressive $48.8 \%$ of the vote, losing only marginally to the DPS candidate, Filip Vujanović, who won $51.2 \%{ }^{51}$

The DF's rise was somewhat demonstrative of a potential shift in the distribution of power among the opposition parties. The narrow margin of the defeat had demonstrated that the DF, certainly under Lekić's stewardship, was a credible and ascendant political force. Despite the DF's notable early successes, however, cracks soon began to appear. Speculation that Lekić disliked the hard-line positons that NOVA adopted vis-à-vis Serb national issues had been abundant throughout the DF's rapid ascendancy, but strains within the DF were evident by 2014. Indeed, after internal disagreements over the direction of the coalition, Lekić departed in March 2015 to form his own party Demokratski savez (Democratic Union, known more commonly as DEMOS), taking a number of key DF members with him, including Goran Danilović, the former vice president of NOVA. The DF, after the departure of Lekić, did not possess the level of support that its original incarnation enjoyed, but his departure allowed the more radical elements within the DF to re-orient the coalition to a more radical position that would have been impossible under Lekić's leadership. So though seemingly weakened as a political force, they changed direction, opting not to challenge the DPS within the parliament but to resort to a parliamentary boycott and to a return to the 'politics of the streets'.

\section{The Democratic Front and the 'Politics of the Streets'}

The DF began their round-the clock anti-government protests, which, of course, the government deemed 'unlawful', on 27 September 2015 by erecting a 'tent city' outside the parliament building, which organisers described as the 'first free territory in Montenegro'. ${ }^{52}$ Behind the scenes, DF activists were endeavouring to give the protests a distinct 'brand'. Under the banner Sloboda traži ljude (Freedom Seeks People), they launched a dedicated website (slobodatraziljude.me), a Facebook page and a Twitter account (FreedomCalling.me), their stated aim being to 'crowd-fund the revolution', a rather innovative initiative and certainly novel in the Montenegrin context. ${ }^{53}$ This and other-somewhat opaque-means of funding proved successful enough for the DF, if nothing else, to purchase a large number of tents in

\footnotetext{
${ }^{51}$ VIP Daily News Report, Belgrade, 9 April 2013, 4.

${ }^{52}$ Darvin Murić, 'Pat pozicija na bulevaru kod Skupštine', Vijesti, Podgorica, 4 October 2015, 3.

${ }^{53}$ For information on 'crowd funding' see the Sloboda traži ljude website: http://slobodatraziljude.me/doniraj/ [last accessed 13 January 2017].
} 
advance of their protests. The Montenegrin government, and media close to them, claimed the DF was, in fact, funded by a network of Serb nationalists with ties to Russia. ${ }^{54}$ Undeterred, the leadership of the DF declared that the protests were not anti-NATO, that they were seeking fair elections, and would continue their protests until the government resigned and a 'technical government' was installed to oversee preparations for Montenegro's 'first free and fair elections'. More specific demands included the creation of an electronic electoral roll to prevent the manipulation of voter registration, the preparation and passing into law of legislation designed to mitigate the abuse of state resources for DPS supporters. ${ }^{55}$

But such ambitious demands could only be met by mobilising sufficient numbers, and there was little evidence to suggest that they would be able to do so. The problem was both one of numbers and of image. Despite the modern, social media-savvy image that the DF attempted to project, the organisers of the protests were well-known opposition figures with a lengthy record in opposing the DPS. Given their profile, it seemed improbable that they could appeal to an electorate beyond those who were their natural supporters, and thus equally improbable that they could meet their stated objectives. ${ }^{56}$ Indeed, the early stages of the DF protests, in late September 2015, appeared to bear this out. Though their campaign was energetic the relatively small numbers involved indicated that they had failed to capture the imagination of the wider public and thus presented little or no threat to the government, who dismissed them as meaningless and led by the 'usual suspects'. ${ }^{57}$

By 17 October 2015, the small number of tents located outside the parliament gave the distinct impression that momentum had stalled. Indeed, just as it appeared that the protests had run out of steam, after twenty days of protest, the government took the decision to clear the 'tent city', on the pretext that it was an inconvenience to citizens. ${ }^{58}$ During the subsequent police operation minor stand-offs between police and demonstrators took place, though tensions quickly rose. Riot police intervened in a rather 'heavy handed' manner, with both DF activists and ordinary citizens subjected to rough treatment. In any event, the harsh nature of

\footnotetext{
54 See, for exapmle, I.P., 'Pad valde ili ćemo u subotu svi na ulicu', Pobjeda, Podgorica, 26 October 2015, 2.

${ }_{55}$ M.R. 'DF traži samo poštene izbore', Vijesti, Podgorica, 8 October 2015, 2.

56 The Montenegrin writer Andrei Nikolaidis stated that the protests represent an attempt to stage a 'Chetnik revolution in Podgorica'. See Andrej Nikolaidis, 'Samo čitam stare novine', Slobodna Bosna, Sarajevo, 22 October 2015, 24.

${ }^{57}$ Darvin Murić, 'Amfilohije govorio o evropi na protesta fronta: Bombardovali nas a mi hrlimo njima', Vijesti, Podgorica, 5 October 2015, 3.

${ }^{58}$ Pobjeda, Podgorica, 18 October 2015, 2. Pobjeda consistently referred to the DF demonstrations as 'anti-NATO demonstrations', and, equally consistently, made the case that Russia were behind them. See, for example Pobjeda, Podgorica, 19 October 2015, 3.
} 
the police operation (they would later use stun grenades and tear gas to disperse the protestors), while facilitating the dispersal of the protestors, played straight into the hands of the DF.

The excessive force used by the police in dismantling the 'tent city' later, during the subsequent protests, presented the DF with the opportunity not to cast themselves as victims of 'police brutality' and 'state oppression', but to reach out to the wider citizenry. Evidently adept at using social media, DF activists captured (largely on mobile phones) numerous images of police restraining and beating demonstrators, which were then disseminated through Facebook and Twitter. This worked to good effect. The vast majority of major international press agencies, for example, simply conveyed the DF narrative without providing much by way of context. Others entered the 'debate' following the breaking of the protests. On 17 October 2015 Doris Pack, the EU's former head of the European Parliament delegation for Southeastern Europe, wrote on her Twitter account that in Montenegro the 'autocratic Prime Minster has set himself above the law, arresting peaceful protestors'. One week later, on the day of the 24 October protests (see below), she tweeted that the protests were 'not against NATO but against Djukanović, ${ }^{59}$ The government, conversely, appeared to have no equally effective narrative to justify the actions of the police, and thus the images of the events of that evening changed the dynamics dramatically, exceeding even the expectations of the protest's organisers. The moral victory — and the propaganda gains generated through the effective use of social media—was theirs.

The violent removal of the tent-dwellers in front of the parliament of 17 October 2015, by accident or design provided the DF with an opportunity to mobilise larger numbers to their cause. And, indeed, on the following evening a significantly larger crowd descended on the Square of the Republic to demonstrate against the brutality of the police and, more generally, the government. The Montenegrin government were on the defensive; not close to collapse by any means but rattled by the course of events nevertheless. Understanding that the dynamics had shifted, and seeking to capitalise, the DF announced that they were giving the government 'six days to resign' or large demonstrations in Podgorica would go ahead the following weekend. ${ }^{60}$ They called on citizens of Montenegro and opposition parties to join them. And by early evening on Saturday 24 October 2015 it was evident that the numbers gathered in the centre of Podgorica far outstripped those of previous demonstrations. Sensing that it was time to seize the opportunity, the DF's leaders, perhaps themselves surprised at the scale of the

\footnotetext{
${ }^{59}$ See Vijesti, Podgorica, 25 October 2015, http://www.vijesti.me/vijesti/doris-pak-ostavka-dukanovica-i-izboripo-novim-pravilima-857377. [last accessed 10 January 2016].

${ }^{60}$ S. Kajošević, 'Djukanović do subote da podnese ostavku', Vijesti, Podgorica, 19 October 2015, 4.
} 
gathering and realising that they may never mobilise such numbers again, sought to harness the anger and energy of the crowd. After a series of emotive speeches, they appealed to the crowd to join them in marching on the Montenegrin Assembly. But though there were many thousand protestors present who shared feelings of discontent and a sense of injustice, what became equally evident was that a far smaller number would be willing to join the DF in their attempts to overthrow the government 'from the streets' ${ }^{61}$ Thus, as the rally concluded, a smaller, though still significant, number of protestors walked towards the parliament, encouraged to do so by the DF's leaders. There, the crowd became increasingly agitated and the atmosphere, defiant though largely jovial just an hour before, turned darker. A small number of demonstrators began to throw rocks and firecrackers at the police that had encircled the assembly, before surging towards the police lines. Thereafter, the Special Anti-Terrorist Unit (Specijalna antiteroristička jedinica, SAJ) responded with tear gas and baton charges. ${ }^{62}$ The centre of Podgorica descended into chaos.

In the immediate aftermath the government sought to retake both the initiative and the moral high ground. Having been caught off-guard by the social media activism of the DF the previous weekend, the government ensured that they prevailed in this particular information war. The Montenegrin government argued that the evening's events were an attack on the state. Seeking to discredit the DF, Milo Djukanović described the protestors' actions as an attempted coup d'état, while stating that the DF were 'Serbian and Russian proxies seeking to reverse Montenegro's path to NATO membership and undermine' Montenegro's statehood. ${ }^{63}$ The (pro-government) daily Pobjeda claimed on 26 October 2015 that 'Serbian and Russian extremists' were providing logistical support to the $\mathrm{DF}^{64}$ and that the Serbian extreme nationalist groups Nacionalni stroj (National Alignment) and Obraz (Honor) had organized and participated in the violence. ${ }^{65}$ It should be pointed out, however, that Djukanović since has emphasized on numerous occasions that he believed the government in Serbia have had

\footnotetext{
${ }^{61}$ Despite the large number of people present at the 24 October demonstrations, a poll conducted in November 2015 by the Center for Democracy and Human Rights (Centar za demokratiju i ljudska prava, CEDEM) showed that support for the DF among citizens most likely to vote for the opposition, while having risen by almost $3 \%$ since June, peaked at only $8.7 \%$ in November 2015. DEMOS and its coalition partners, by contrast, stood at 21.1 \%. See CEDEM, 'Političko javno mjenje Crne Gore', Podgorica, November 2015, 8.

62 There were numerous accounts of protestors being severly beaten by members of the SAJ. See Milena PerovićKorać, 'Milove beretke', Monitor, Podgorica, 30 October 2015, 7-9.

${ }^{63}$ Pobjeda, Podgorica, 31 October 2015, 2.

${ }^{64}$ N. Zečević \& D. Djuranović, 'Mreza: Podgorica-Beograd-Moskva', Pobjeda, Podgorica, 26 October $2015,1$.

${ }^{65}$ N. Zečević, 'Nacionalni stroj i Obraz izazivali haos u Podgorici', Pobjeda, Podgorica, 28 October 2015, 2.
} 
absolutely no role in supporting the DF protests. (Indeed, both Vučić and Djukanović are close associates and both are advised by Vladimir Beba Popović). ${ }^{66}$

To be sure, in seeking to harness that anger the DF miscalculated. By issuing unrealistic ultimatums and attempting to storm the parliament building they, within one hour, transformed themselves from perceived victims into perceived aggressors, and the voices and reasoned arguments of the more civic-oriented within the DF were immediately obscured by those with a more radical orientation. If the DF had been indeed capable of channelling widespread dissatisfaction and transforming the protests into a broader citizens' movement, their chance had, most likely, gone with the wind. In the wake of the violence, the DF sought to limit the damage, arguing that those responsible for the violence had been 'placed' by Montenegro's National Security Agency (Agencija za nacionalnu bezbjednost, ANB) to discredit the DF and undermine the legitimacy of the protests.

In the midst of an increasingly febrile domestic political context, relations between Podgorica and Moscow further deteriorated as it became evident that Montenegro would indeed join NATO. The situation had started to worsen following the Montenegrin government's support of EU sanctions against Russia in July 2014. This not only generated sharp criticism from the Russian Ambassador in Montenegro, Andrei Nesterenko, but from his counterpart in Serbia, Alexander Chepurin, who commented that the Montenegrin government's attempts to join NATO were akin to 'monkeys chasing a banana' ${ }^{67}$ Thereafter a number of anti-Russian billboards appeared in Podgorica emblazoned with messages such as 'Better a banana in the hand than a Russian boot in the neck', and one that drew on a quote from the Montenegrin communist, writer, and then dissident, Milovan Djilas: 'Russians have never been friends to Montenegrins; we have always been bargaining chips to them'. ${ }^{68}$ Thereafter, Montenegrin government claims that Russia had been behind the October 2015 protests fuelled a further deterioration of bilateral relations. ${ }^{69}$ Yet while little concrete evidence was provided to prove that Russia has anything other than rhetorically supported the DF (and anti-NATO) protests, the Montenegrin government has not deviated from the narrative linking the two. Djukanović argued that Russia continued to interfere in the political life of

\footnotetext{
${ }^{66}$ See, for example, Radio Slobodna Evropa, 'Djukanović: Russia is Meddling in Montenegro, 18 December 2015, http://www.slobodnaevropa.org/content/djukanovic-russia-is-meddling-in-montenegro/27435598.html [last accessed 14 January 2016].

67 Vijesti, Podgorica, 9 May 2014, 4.

${ }^{68}$ See Petar Komnenić, 'Russia Protests over Anti-Russian Billboards in Montenegro', Reuters, 28 November 2014, http://uk.reuters.com/article/uk-montenegro-russia-billboards-idUKKCN0JC13920141128 [last accessed 13 January 2016].

${ }^{69}$ See Darvin Murić, 'Marković: Imamo dokaze da Rusija pomaže proteste', Vijesti, Podgorica, 23 October 2015, 3.
} 
Montenegro, though stating that Montenegro's damaged relations with Moscow was primarily a 'collateral effect' caused by current geopolitics and a reflection more of Russia's own deteriorating relationship with NATO. ${ }^{70}$

Montenegro's formal invitation to join the NATO alliance, received on 2 December 2015, to become NATO's twenty ninth member, saw a shift in the DF's strategy-with more focus being placed on a 'No to NATO' campaign, inspite of continuing to work towards creating the conditions for a transitional government. An anti-NATO protest went ahead in Podgorica on 12 December 2015, which however was organised by NOVA and thus not strictly by the DF. Speakers expressed outrage that Montenegrin troops may be deployed in neighbouring Kosovo as part of NATO-KFOR (Kosovo Protection Force). They were joined on stage by a 'special guest', the former Montenegrin president and SRJ prime minister Momir Bulatović, who opined that the government were forcing the country into NATO 'to avoid being held responsible for their criminal activities'. ${ }^{71}$ Subsequent speakers warned of the possibility of an armed uprising against the government if the decision to join NATO was taken without a referendum. ${ }^{72}$

\section{The October 2016 Parliamentary Elections and the Alleged 'State Coup'}

In spite of surviving a vote of no confidence and caving-in to pressure by creating an 'interim government', comprising members of opposition parties in key roles, the DPS prepared for Montenegro's 'free and fair elections', scheduled to take place in October 2016. At the same time, the country celebrated the ten-year anniversary of the restoration of its independence. A distraction from the ongoing political crisis, it was a more muted affair than might have been expected. In any event, the tone and content of the pre-election campaigns was as anticipated. The DPS claimed that a vote for them would be a siguran korak (safe step): a vote for stability, economic growth, increased investment in the country's infrastructure, and an affirmation of Montenegro's independence and future integration into NATO and the EU. But even the upper echelons of the DPS seemed acutely aware of the potential for an uncertain outcome. In mitigation, they launched an energetic campaign, during which Djukanović warned that the stakes were high and that the DPS were faced with an opposition that was unpatriotic, irresponsible, treacherous and willing to 'jeopardise public peace and order,

\footnotetext{
70 See Radio Slobodna Evropa, 'Djukanović: Russia is Meddling in Montenegro, 18 December 2015, http://www.slobodnaevropa.org/content/djukanovic-russia-is-meddling-in-montenegro/27435598.html [last accessed 14 January 2016].

${ }^{71}$ M.B. 'Odkula na referendumu ili će biti nemira', Dan, Podgorica, 13 December 2015, 3.

72 'Ne bude li referenduma biće narodni ustanak', Vijesti, Podgorica, 13 December 2015, 2-3.
} 
violating laws and undermining state institutions' to gain power. He also stated that he saw no justification for anyone in Montenegro giving their vote to those who were trying to 'stop Montenegro dead in its tracks' ${ }^{73}$ In this regard, the DPS leadership singled-out the DF as those most likely to cause trouble during elections. The DF were, they argued, a dangerous and untrustworthy group who were not only attempting to undermine Montenegro's sovereignty, but were accepting money from Russia to finance their 'anti-Montenegrin' and 'anti-NATO' campaign.

Aware of growing discontent, opposition parties attempted to capitalise by emphasising the need for a change of government after 27 years of DPS rule, growing unemployment and high-level corruption. They also claimed throughout their campaign that the DPS had used state resources to provide various 'incentives' such as the writing-off of utility bills and purchasing identity cards to buy votes. The DF's campaign was well organised and relatively glossy; it gained momentum as the election approached. According to an OSCE/ODHIR report, interlocutors with their own election monitors alleged that 'the high quality and quantity of DF campaign materials' was due to the coalition 'receiving foreign funding'. The report, however, provided no concrete evidence of this. ${ }^{74}$ The Ključ (Key) coalition-comprising the Democratic Alliance (DEMOS), the SNP and the civic movement United Reform Action (Ujedinjena reformska akcija, URA) — claimed, for example, that the DPS had plundered Montenegro's wealth and had been an abject failure in government. On the face of it, the opposition appeared in a strong position to challenge the DPS. If united, they could be stronger than the ruling party. And yet the opposition gain failed to do so when it mattered. The DF, Key and the newly founded split off of the Socialist People's Party, the Democratic Montenegro party (Demokratska Crna Gora, DCG) implied that a post-election coalition was possible and that a 'good basis' for a ruling coalition involving opposition parties existed. For other opposition parties prospects were mixed: The SDP and PCG were in a fighting for their very survival. Conversely, they could be kingmakers, deciding whether to enter a coalition with the DPS or unite with in a grand coalition.

As the election drew closer, the exchange of accusations intensified. The DPS alleged that the DF may, in the event of a DPS victory in the election, attempt to destabilise Montenegro. Djukanović warned that the government would respond firmly to 'any attempts

\footnotetext{
${ }^{73}$ Vesna Šofranac, 'Izbori 16. oktobra biće istorijska potvrda referenduma', Dnevne novine, Podgorica, 14 October $2016,2$.

${ }^{74}$ See OSCE/ODHIR International Election Observation Mission, 'Montenegro - Parliamentary Elections, 16 October 2016, Statement of Preliminary Findings and Conclusions’, Podgorica, 17 October 2016, 7.
} 
at jeopardising public peace and order, violating law and undermining state institutions' ${ }^{75}$ Thereafter, the Director of the Montenegrin Police, Slavko Stojanović, announced that not only were the police prepared for riots during election day and after, but that his organisation possessed 'operational information' that suggested that certain (opposition) elements may attempt to instigate unrest and that the police were 'prepared for such incidents' ${ }^{76}$ In a surprising twist, Montenegrin police began to reveal details of what they argued was an attempted 'state coup'. Just two days before the election, a former policeman, Mirko Velimirović, entered a police station in Podgorica and revealed that a plot to install a 'proRussian' government had been prepared. On the basis of the information provided by Velimirović, Montenegrin police arrested Bratislav Dikić, a former Serbian gendarmerie member who, they alleged, was part of an armed criminal organization that aimed to subvert the election process and to attack citizens and police officers near government buildings in Podgorica. Dikić immediately denied involvement, claiming that he had been 'framed' during a visit to Montenegro, where he had come to visit Ostrog monastery near Nikšić on account of his ill-health. Ostrog monastery, set in the large rock of Ostroška Greda, is a place of pilgrimage for many Orthodox Christians (and of other faiths). It is known for being the location of the bones of Sveti Vasilije (Saint Basil) of Ostrog, and pilgrims who are suffering ill-health believe they can be cured or their pain eased by praying next to his body. In an interview for Dan, Dragan Dikić, Bratislav's brother, claimed that his brother had gone to Ostrog for this reason and that he was not only 'gravely ill' having undergone an operation due to a form of cancer, but had, since the operation, difficulty speaking. ${ }^{77}$ In adition to Dikić, nineteen more Serbian citizens were also arrested in what the government claimed was an attempt to stage a coup d'état during which Djukanović would be the target of an assassination attempt.

On polling day turnout was relatively high (compared to elections in 2009 and 2012), and by 8 p.m., when polling stations closed, $73.2 \%$ of those eligible to vote had done so. The day was tense and not without incident, and to add to the sense of crisis, Montenegro's Agency for Electronic Communications (Agencija za elektronske komunikacije, AEK) ordered all of the country's three mobile operators to bar the use of the Viber and WhatsApp messaging services - used quite effectively by opposition parties, particularly the DF-, on the pretext that a significant volume of 'spam' was being sent via mobile networks. As early results came

\footnotetext{
${ }^{75}$ Vesna Šofranac, 'Izbori 16. oktobra biće istorijska potvrda referenduma', Dnevne novine, Podgorica, 14 October $2016,3$.

76 'Na dan izbora moži doći do neredi', Dnevne novine, Podgorica, 14 October 2016, 6.

${ }^{77}$ See D. Živković, 'Ljubi iz CAJ-a prije hapšenja dolazili kod mog brata', Dan (Podgorica), 20 October $2016,3$.
} 
in, it was evident that while the DPS vote did not collapse they had only achieved a relative majority, failing to garner enough votes to secure a parliamentary majority ( $41.4 \%$ of the vote and 36 seats in parliament). The opposition, particularly the DF, performed well with $20.3 \%$ of the vote and 18 seats, opening the possibility of a governing coalition should the DPS fail to secure enough support from potential coalition partners. The Key coalition secured only $11 \%$ of the vote and nine seats; the DCG gained eight seats, while the SDCG won two seats.

As the party with the largest share of the vote, it was incumbent on the DPS to attempt to form a governing coalition; one that would possess at least 41 of the 81 seats in the Montenegrin Assembly. The new government, which included many new faces, was eventually formed on 28 November 2016, but it was not its formation that became the Montenegrin new government's primary problem, but rather claim and counter-claim over the existence of a socalled 'state coup', with the Montenegrin government providing what they claimed was evidence of an organised coup attempt. On 17 October 2016, the Montenegrin State Prosecutor, Ivica Stanković, had announced that the government had 'reasonable suspicion' that an 'organised criminal group' (comprising twenty Serbian citizens and led by Bratislav Dikić) had plotted to launch a coup d'état on the day of the election. ${ }^{78}$ Thereafter, the government released what they claimed were transcripts of a conversation between Dikić and one Aleksandar Sindjelić - a Serbian citizen who allegedly fought for the Novorossiya (New Russia) forces in Eastern Ukraine — who was accused of being one of Dikić's co-conspirators. ${ }^{79}$ Three days later Montenegro's special prosecutor for organised crime, Milivoje Katnić, appeared on the television programme Načisto to tell the host, Petar Komnenić, that the government had evidence that 'terrorists' had, on the evening of 16 October 2016, planned to embed themselves within a group of protestors assembled outside parliament, before entering the building dressed as police officers to take over the Montenegrin Assembly by force of arms and announce that the 'party of their choice' had won the election. Only quick action on behalf of Montenegro's security services, he said, had prevented Montenegro 'from being shrouded in black' ${ }^{80}$ The reaction to Katnić's interview was, predictably, mixed: the DF, for example, argued that there were many unanswered questions and that Katnić's appearance on the show was

\footnotetext{
78 A. Gagović \& D. Djuranović, 'Potraga za Dikićevim jatacima iz Crne Gore', Pobjeda, Podgorica, 18 October 2016, 8-9.

${ }^{79}$ According to a report in Pobjeda, Sindjelić had fought with pro-Russian rebels in Eastern Ukraine in 2014 and 2015. Citing a Ukrainian web portal, Teror, they claimed that Sindjelić was proclaimed a terrorist by the Ukrainian president Petro Poroshenko and his cabinet. See N. Zečević, 'Sindjelić bio na čelu srpskih dobrovoljaca u Novorusija', Pobjeda (Podgorica), 5 November 2016, 11.

${ }^{80}$ Načisto, TV Vijesti (Podgorica), broadcast on 20 October 2015. The full interview with Milivoje Katnić can be found at https://www.youtube. com/watch?v=QnuNtGgePn0 [last accessed 21 December 2016].
} 
'scandalous'. ${ }^{81}$ However, on 24 October 2016, the Serbian prime minster Aleksandar Vučić announced that arrests had been made in Serbia connected to the coup attempt, a development that appeared to lend credence to the Montenegrin government's claims. Vučić added, however, that those arrested in Serbia (including three Russian citizens) appeared to be unconnected to those arrested in Montenegro. ${ }^{82}$

The growing controversy was interrupted briefly with the news that Milo Djukanović would step down as prime minister. During the election campaign there had been no evidence that Djukanović had tired of frontline politics. Yet having already heavily implied that he considered Duško Marković to be the man to form a new government, Djukanović formally announced on 28 October 2016 that he would be retiring (amid denials that he was under pressure from the US to do so. Duško Marković, the former head of Montenegro's state security, had been nominated by the main board of the DPS to succeed him. ${ }^{83}$ Dubbed by the opposition as the crna kutija (black box) of Montenegrin politics (or even as the 'Putin from Mojkovac'), Marković's past meant that he was both respected and feared. No-one, perhaps, has had his finger so firmly on the pulse of social and political developments in Montenegro, and while he is not a slick as Djukanović, he is, undoubtedly a shrewd and highly capable operator and one that can enforce discipline within the DPS.

While Marković proceeded with the creation of a DPS-led governing coalition, the 'state coup' controversy took numerous twists and turns. On 27 October 2016 Aleksandar Vučić revealed that the Serbian Security Information Agency (Bezbednosno-informativna agencija, BIA) had proof that 'certain groups' were closely monitoring Djukanović's movements, while also revealing that 125,000 euros and a number of stolen Montenegrin police uniforms (to be worn, allegedly, by the attackers) had been seized. ${ }^{84}$ Two Russian citizens (named as Eduard Vladimirovich Shirokov and Vladimir Nikolaevich Popov) who were alledged to have been members of Russian Military Intelligence and had been held in Serbia, were permitted to return to Moscow after a visit to Belgrade by Nikolai Patrushev, a senior Russian security official. ${ }^{85}$ However, on 1 November 2016, the above-mentioned Aleksandar Sindjelić turned himself over to the Montenegrin authorities, having been visited by them in

\footnotetext{
${ }^{81}$ D. Živković, 'Katnić sam sebe uhvatno u lažima oko naoružavanja “terorista"', Dan, Podgorica, 22 October 2016, 3 .

82 Vijesti, Podgorica, 25 October 2016, 11. See also Pobjeda, Podgorica, 25 October 2016, 4.

${ }^{83}$ N. Zečević, 'Duško Marković predložen za mandatara', Pobjeda, Podgorica, 26 October 2016, 2.

84 'Milovo ubistvo nisam pominjao', Dan (Podgorica), 28 October 2016, 4.

85 'Russia Appears to Cause Trouble in the Balkans' The Economist (London), 4 November 2016, http://www.economist.com/node/21709635/ [last accessed 9 December 2016].
} 
Belgrade during the previous week. ${ }^{86}$ However, the waters were muddied even further regarding Sindjelić's role in the 'state coup'. The leader of Serbia's Ravna Gora Movement, Bratislav Živković, claimed that Sindjelić had been offering money to members of the group to go to Podgorica, but that many refused because it was widely suspected that he was cooperating with both Serbian and Montenegrin intelligence services. ${ }^{87}$ While in custody, Sindjelić negotiated a plea-bargain that would mean a more lenient prison sentence, if he agreed to provide prosecutors with specific detailes about the planning of the attack. Apparently on the basis of this information, the Montenegrin prosecutor, Milivoje Katnić, declared thereafter that a plan resembling a 'Ukrainian scenario' had been uncovered—whereby the attacks on the Montenegrin Assembly and the arrest of Milo Djukanović would be used to cause panic, unrest and a destablisation of Montenegro - all with the aim of halting the country's accession to NATO ${ }^{88}$ The DF's response to this was simply that the state prosecutors were siding with the DPS, which had fabricated the entire case. ${ }^{89}$

In the meantime, on 7 November 2016, the new Montenegrin government was formally constituted at a ceremony in Cetinje, after tough negotiations between the DPS and a number of minority parties. Neither the DF nor the Key members of the assembly were in attendance, and the DCG and SDP members were similarly conspicuous by their absence. All stated that they did not recognise the result of the election and that they would not return to parliament until the 'state coup' was investigated by an independent commission..$^{90}$ Further developments in the investigation of the alleged state coup hardened their resolve to continue with their boycott. On 24 November 2016, Aleksandar Sindjelić, hitherto the main suspect in the 'state coup' case, was released from Spuž prison near Podgorica, having been given the status of a 'protected witness' by the Montenegrin High Court, and permitted to return to Belgrade on the basis that he would continue to assist the prosecutors. Thereafter Montenegrin prosecutors applied pressure on the leaders of the DF, and the accusations that they had been involved in the alleged coup continued. As the daily Dan claimed in an article published on 26 December 2016, however, there existed 'reasonable doubt' that part of the evidence in the state coup case had not been falsified by the prosecutors. The newspaper mentioned documentation in which

\footnotetext{
${ }^{86}$ Jelena Jovanović, 'Sindjelić došao da bi ga uhapsili', Vijesti (Podgorica), 3 November 2016, 14-15.

${ }^{87}$ D.Živković, 'Dobrovoljcima za Ukrajinu plačao da dodju u Crnu Goru kako bi inscenirali tororizam', Dan (Podgorica), 6 November 2016, 2. For the role of Živković and other Serbian volunteers in Eastern Ukraine see Nidžara Ahmetašević, 'Strani plaćeni u Ukrajini, prijetnja za Europu', Slobodna Bosna (Sarajevo), 2 April 2015, 36-40.

${ }^{88}$ N. Zečević, 'Sjenka ulrajinskog scenarija', Pobjeda, Podgorica, 8 November 2016, 2.

${ }^{89}$ M.R., 'Tužioci pomažu vlada DPS-u', Vijesti, Podgorica, 8 November 2016, 2.

${ }^{90}$ D. Živković, 'Mandić: Katnić pomaže Milovoj kriminalnoj vlada', Dan, Podgorica, 8 November 2016, 3.
} 
two of the alleged conspirators (Aleksandar Sindjelić and Mirko Velimirović) are listed as having used the same phone number when discussing their plans, which was, the author argued, 'technically impossible'. ${ }^{91}$ This was merely one controversy in what has been a long and somewhat bizarre legal process. The trial of the accused continued throughout 2017 and has not, at the time of writing, reached a conclusion.

\section{Conclusion}

Montenegro has experienced significant flux in the past two decades and has made significant strides since the dark days of the 1990s. Once a junior member of a federation (the SRJ) that was, two decades ago, an international pariah, Montenegro is now an independent state, a formal EU candidate, and a member of NATO. Thus, the stated objective of the DPSled government (in its various forms) has been partially achieved. From an external perspective Montenegro's trajectory appears very positive. Internally, however, the country faces significant challenges. Montenegro's independence is viewed, even among those who voted for it, as a DPS-led project that had, in the main, benefited members of that party and not Montenegrins broadly. Moreover, the ongoing internal political crisis shows little sign of abating, and the political environment is, perhaps, more febrile than at any stage since the 2006 referendum. The continuing parliamentary boycott by the opposition and the upcoming trial of key leaders within the DF, alleged to have been involved in the 'state coup' attempt of October 2016, will determine that the political environment will remain challenging for some time to come.

Despite the growing dissatisfaction, however, the opposition have been unable to sufficiently unite to challenge the DPS, and thus Montenegro remains the only state in Southeastern Europe that has been governed, uninterrupted, by the same political party (albeit with a split within the DPS in 1997) since the first multi-party elections in 1990. There has been no change of government through the mechanism of democratic elections. Political change, such as it is, has been generated from within the DPS. The DPS is a 'state party' and, to some extent, the party is the state. The party's well-established control over the instruments of state awards them a significant advantage over the opposition. Moreover, the patronage of those in power is crucial to employment (particularly to those who work in the public sector) and social advancement.

\footnotetext{
${ }^{91}$ See 'Falsifikovani transkripti o Milovom hapšenju', Dan, Podgorica, 26 December 2016, 10.
} 
Amid internal splits within opposition parties and the aforementioned legal process against the DF, no opposition politician has yet emerged that has proved robust enough to mount a significant challenge to Milo Djukanović and the DPS. In fact, neither his latest stepping down from office heralded fundamental political change, merely a change of stewardship. (This was, after all, his third departure from the role of prime minister in a decade). On both occasions he not only chose who would succeed him, but he remained a powerful and influential figure within the party, albeit operating from behind the scenes. He remained the chairman of the DPS, giving him oversight of party developments and considerable influence over party matters. He has stated that he will be 'helping' Marković to govern Montenegro when his experience is called upon. Much like his departure from formal political roles in the past, therefore, it was unlikely that Djukanović would retreat into quiet retirement. Indeed, after a long delay in naming their candidate, the DPS announced that Djukanović would be their candidate for the presidency. He won the presidential campaign convincingly in April 2018. So while the last three decades have been characterised by flux (as is the contemporary political landscape), there has been a marked continuity in Montenegro's political leadership throughout that journey.

\section{CORRESPONDING AUTHOR}

Kenneth Morrison De Montfort University, Faculty of Arts, Design and Humanities, School of Humanities, The Gateway, Leicester LE1 9BH, United Kingdom. E-mail: kmorrison@dmu.ac.uk 